\title{
Freshwater vertebrates monitoring in Maninjau Lake, West Sumatra, Indonesia using environmental DNA
}

\author{
DEWI IMELDA ROESMA`, DJONG HON TJONG, MUHAMMAD NAZRI JANRA, DYTA RABBANI AIDIL \\ Department of Biology, Faculty of Mathematics and Natural Sciences, Andalas University. Jl. Universitas Andalas, Limau Manis, Pauh, Padang 25163, \\ West Sumatra, Indonesia. Tel./fax.: +62-751-71671, `email: dewiroesma@sci.unand.ac.id.
}

Manuscript received: 17 March 2021. Revision accepted: 23 April 2021.

\begin{abstract}
Roesma DI, Tjong DH, Janra MN, Aidil DR. 2021. Freshwater vertebrates monitoring in Maninjau Lake, West Sumatra, Indonesia using environmental DNA. Biodiversitas 22: 2794-2802. Environmental DNA (eDNA) is one of the DNA sources without directly disturbing the organisms. The eDNA potentially an effective method with next-generation sequencing (NGS) that can read all DNA in parallel at one sequential run. Maninjau Lake in West Sumatra has experienced a decline the species richness, thus monitor biodiversity with the non-invasive method is needed. This study aimed to apply eDNA for monitoring freshwater vertebrates in Maninjau Lake. The eDNA was collected from water samples using the filter membrane to DNA isolation and sequencing with the NGS technique from Illumina. The eDNA method detected 150 vertebrate individuals and consists of 92 Actinopterygii fishes, three chondrichthyes fishes, 11 amphibians, seven reptiles, ten aves, and 27 mammals. Among all individuals were detected, only 11\% known present in Maninjau Lake, while the others (89\%) are native species to other countries. The fishes were detected living in Maninjau Lake by the eDNA method, i.e., Cyprinidae (Carassius auratus and Cyprinus carpio), Cichlidae (Oreochromis niloticus), and Poeciliidae (Gambusia affinis and Xiphophorus maculatus). Bias results in this study to be influenced by various factors i.e., possibility of contamination, poor DNA quality, the bias results during molecular processes, and not available the complete sequences databases to assigned into the correct taxa, especially fish species in Maninjau Lake. The eDNA method for monitoring biodiversity should consider the increase of sampling sites, replication samples, and the availability of sequences database in Genbank, NCBI.
\end{abstract}

Keywords: Environmental DNA, Maninjau Lake, next-generation sequencing, vertebrates

\section{INTRODUCTION}

Environmental DNA (eDNA) is a part of DNA fragments released by organisms into the environment, such as water, air, soil, or sediment through the skin, urine, feces, mucus, and dead cells (Foote et al. 2012; Taberlet et al. 2012). The eDNA was first introduced as a microbial DNA extraction method from sediment samples by Ogram et al. (1987). Since the 2000s, eDNA has been used to assess the microorganism's community (Willerslev et al. 2003) and developed to estimate the biodiversity from various ecosystems. The eDNA method has some advantages compared to the conventional method since it is a non-invasive method (environmentally friendly) without disturbing species and habitat and also efficient in using cost and times for identifying species (Ficetola et al. 2008; Goldberg et al. 2011).

The eDNA method has been developed in many studies from the various taxa and habitats, such as detection of aquatic invasive species (Nathan et al. 2014) and endangered species (Laramie et al. 2015), monitoring of marine vertebrates (Andruszkiewicz et al. 2017), detection of common carp in the lake (Eichmiller et al. 2014; Takahara et al. 2015), invertebrates biodiversity (Treguier et al. 2014), and detection animal and plant communities from soil (Yoccoz et al. 2012; Deiner et al. 2017).

The eDNA samples contain DNA mixtures from hundreds to thousands of individuals, which requires an efficient method for sequencing all DNA in parallel (Shokralla et al. 2012). NGS (Next Generation Sequencing) is the sequencing technology that can read and generates several million to billions the DNA nucleotides in parallel at one sequential run, with much shorter time and cost compared to the first generation sequencing (Sanger sequencing) (Metzker 2010; Shokralla et al. 2012, 2015).

The fish diversity studies in Sumatra, especially in West Sumatra, Indonesia using the conventional method with direct organism capture has been undertaken for studying fish diversity in West Sumatra Lake (Roesma 2011) and Batang Toru river system (Roesma et al. 2016), genetic diversity of Tor douronensis (Roesma et al. 2017), new record species of Puntius from West Sumatra (Roesma et al. 2018), taxonomy confirmation of Puntius cf. binotatus in Gunung Tujuh Lake (Roesma et al. 2019), and phylogenetic analysis of transparent gobies in three Sumatran Lakes (Roesma et al. 2020).

Maninjau Lake in West Sumatera is used for aquaculture by local people, using floating net cages. In the 2000s, there is evidence of pollution around floating net cages areas (Adrianto et al. 2010; Putri et al. 2020). Maninjau Lake has experienced a decline the species richness from year to year. Weber and de Beaufort (1916) reported that there were at least 33 fish species in Maninjau Lake, while Wargasasmita (1978) reported only found 18 fish species. The last, reported by Roesma (2011) only found 17 species in Maninjau Lake and 8 species in its 
tributary using the conventional method (directly organisms capture), where is between them only found five of native species.

Climate change, human activities, overexploitation, invasive species, and water quality decrease were considered to impact the declining fish species in Maninjau Lake, especially for native species (Adrianto et al. 2010; Putri et al. 2020). The loss of biodiversity continuously will affect the ecosystem's balance (Putri et al. 2020). The conventional method is considered difficult to detect the native species because the declining of population numbers. Therefore, a non-invasive method such as the eDNA method is are needed to monitor biodiversity in Maninjau Lake. The present study aims to detect the freshwater vertebrates using the eDNA method with the NGS technique in Maninjau Lake. The information of monitoring can be used as references to evaluate the biodiversity in West Sumatra waters to determined the conservation management.

\section{MATERIALS AND METHODS}

\section{Procedures \\ Sampling}

The eDNA water samples were collected in August 2018 in Maninjau Lake, West Sumatra, Indonesia (Figure 1) following the protocol by Carim et al. (2016) and Goldberg (2017). All samples were cleaned with $10 \%$ commercial bleach solution and sterilized using the autoclave. The sample collections used disposable nitrile gloves. One L water sample (duplo) was collected using sterile bottles, then kept in a cooling box and carried to the Genetic and Biomolecular laboratory, Departement of Biology, Andalas University for filtration. The ecological data was recorded at the sampling locations such as date, time, Global positioning System (GPS), temperature, and power of hydrogen $(\mathrm{pH})$. The species list identified by Roesma (2011) using the conventional method (direct organisms capture) in Maninjau Lake is shown in Table 1.

\section{Filtration water and DNA extraction}

All equipment for filtration and DNA extraction were cleaned with $10 \%$ bleach solution, rinsed with ethanol Pro Analysis, and then with sterile nuclease-free water. The water collected was vacuum-filtered using a $0.22 \mu \mathrm{m}$ poresized, $47 \mathrm{~mm}$ diameter membrane, Durapore filter membrane (Millipore, MA, USA) with $250 \mathrm{~mL}$ disposable analytical test filter funnels (Nalgene, USA) (Kelly et al. 2014; Andruszkiewicz et al. 2017). After filtration, the filter membranes were removed using sterile forceps to be folded into four folds. The folded membranes were put into $2.0 \mathrm{ml}$ microtubes containing ethanol Pro Analysis to keep the DNA stable. The filter membrane was stored at $-20^{\circ} \mathrm{C}$ before DNA extraction (Carim et al. 2016; Goldberg 2017). The eDNA extraction was carried out in a sterile room to avoid contamination, following the good practices defined in molecular biology laboratories. DNA extraction was performed on the filter membrane using the ZymoBIOMICS ${ }^{\mathrm{TM}}$ DNA Miniprep Kit following the protocols. The DNA quality was checked by electrophoresis with $1.2 \%$ agarose gel. The DNA purity was tested using the Nano Photometer ${ }^{\circledR}$ spectrophotometer (IMPLEN, CA, USA) and quantified using the Qubit ${ }^{\circledR}$ dsDNA Assay Kit in Qubit® 2.0 Fluorometer (Life Technologies, CA, USA).

\section{Library construction and sequencing}

Samples were sent to the Novogene AIT (Singapore) for paired-end library preparation and Next Generation Sequencing (NGS). PCR for paired-end library preparation was constructed using NEBNext ${ }^{\circledR}$ Ultra $^{\mathrm{TM}}$ DNA Library Prep Kit from Illumina (NEB, USA). Index codes were added to attribute sequences to each sample before the PCR. The end of DNA fragments was polished and ligated with the full-length adapter for several hundred base pairs (bp) for Illumina sequencing. Illumina technology (Solexa) utilizes a sequencing-by-synthesis approach. The four nucleotides are added simultaneously to the flow cell channels, and the DNA polymerase was incorporated into the oligo-prime cluster fragments (Mardis 2008). The DNA polymerase generates multiple DNA copies or clusters. Each copy represents the single molecule that initiated the cluster amplification. Each group contains approximately one million copies of the original fragment (Shendure and Ji 2008). PCR products were purified using the Agencourt AMPure XP system. The PCR results were analyzed using real-time PCR and Agilent 2100 Bioanalyzer. According to the manufacturer's instructions, the index-coded samples' clustering was performed on a cBot Cluster Generation System. After cluster generation, the library preparations were sequenced on an Illumina NovaSeq 6000 System platform, and paired-end sequences were obtained.

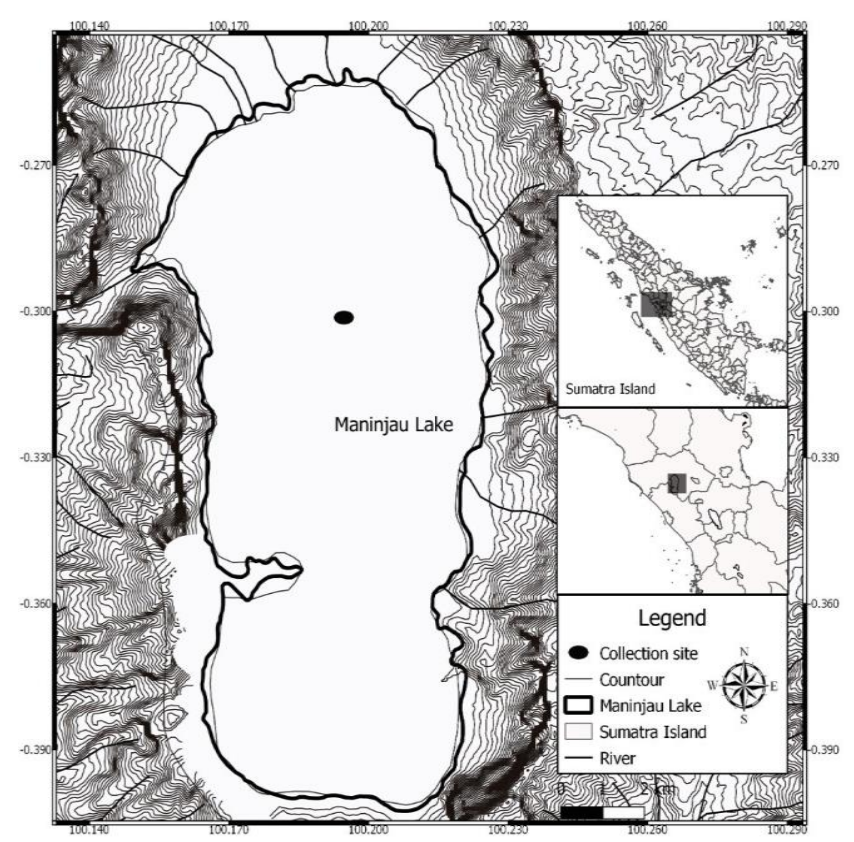

Figure 1. Location of the collection site in Maninjau Lake, West Sumatra, Indonesia 
Table 1. Species recorded by Roesma (2011) in Maninjau Lake with the conventional method

\begin{tabular}{|c|c|c|c|c|c|}
\hline Class & Ordo & Family & Genus & Species & Local name \\
\hline \multirow[t]{25}{*}{ Actinopterygii } & Cypriniformes & Cyprinidae & Barbodes & Barbodes binotatus & Kapareh \\
\hline & & & & Barbodes lateristrigata & Kapareh garis \\
\hline & & & Cyprinus & Cyprinus carpio & Ikan mas \\
\hline & & & Hampala & Hampala macrolepidota & Sasau/barau \\
\hline & & & Osteochilus & Osteochilus hasseltii & Asang \\
\hline & & & Poropuntius & Poropuntius sp. & Sipareh \\
\hline & & & Puntius & Puntius sp. & Sipareh \\
\hline & & & Rasbora & Rasbora jacobsoni & Bada \\
\hline & & & & Rasbora lateristriata & Bada \\
\hline & & & & Rasbora maninjau & Bada \\
\hline & & & Tor & Tor tambra & Gariang \\
\hline & Anabantiformes & Anabantidae & Anabas & Anabas testudineus & Puyu \\
\hline & Siluriformes & Bagridae & Hemibagrus & Hemibagrus velox & Baung \\
\hline & & & Mystus & Mystus sp. & Baung \\
\hline & & Nemacheilidae & Nemacheilus & Nemacheilus chrysolaimos & Tali-tali \\
\hline & & Belontiidae & Trichopsis & Trichopsis vitatta & Sapek \\
\hline & Perciformes & Cichlidae & Cichlasoma & Cichlasoma nigrofasciatum & Zebra \\
\hline & & & Oreochromis & Oreochromis niloticus & Nila \\
\hline & Siluriformes & Clariidae & Clarias & Clarias batrachus & Limbek \\
\hline & & Gobiidae & Gobiopterus & Gobiopterus sp. & Rinuak \\
\hline & Beloniformes & Zenarchopteriidae & Dermogenys & Dermogenys pusilla & Situwuak \\
\hline & Synbranchiformes & Mastacembalidae & Macrognathus & Macrognathus maculatus & Tilan \\
\hline & Angulliformes & Muraenesocidae & Muraenesox & Muraenesox cinereus & Ikan panjang \\
\hline & Cyrpinodontiformes & Poeciliidae & Xiphophorus & Xiphophorus helleri & Ekor pedang \\
\hline & Siluriformes & Sisoridae & Glyptothorax & Glyptothorax schmidti & Situkah \\
\hline
\end{tabular}

\section{Data analysis}

The initial evaluation for sequencing data reading was conducted with the program FastQ. Only paired readings were maintained, and the forward and reverse sequences were merged to produce a mounted FastQ file using the Qiime (Caporaso 2010). Quality control included filtering low-quality and truncated-sized readings were checked to obtain the clean sequence data. The clean data were assembled by SOAP denovo (Luo et al. 2012) and mapped to scaftigs using Soap Aligner Mapping parameter (Qin et al. 2014).

Scaftigs were used for ORF (Open Reading Frame) gene prediction by MetaGeneMark (Zhu et al. 2010; Mende et al. 2012; Karlsson et al. 2013). Data BLAST performed using the MicroNR database to obtain annotation information of the gene catalog. The taxonomic annotation for each unigene was assigned using the LCA (lowest common ancestor) algorithm (Huson et al. 2011). Data BLAST using three databases, i.e. the Kyoto Encyclopedia of Genes and Genomes (KEGG) (Kanehisa et al. 2006, 2014), extending the evolutionary genealogy of genes with enhanced non-supervised orthologous groups (eggNOG) (Powell et al. 2013), and the CarbohydrateActive EnZymes database (CAZy) (Cantarel et al. 2009). Statistical analysis performed using the PCA analysis (Avershina et al. 2013), Anosim, Cluster, and Metastat analysis (White et al. 2009), PATHWAY, Linear discriminant analysis Effect Size (LEfSe), Canonical correspondence analysis/Redundancy analysis (CCA/RDA), and Non-metric multidimensional scaling (NMDS) analysis.

\section{RESULTS AND DISCUSSION}

\section{Results}

The eDNA method with the NGS technique has successfully detected a variety of vertebrate groups. Based on the results, 150 vertebrate individuals were detected classify into six classes, 31 orders, 38 families, 48 genera, 51 species (Table 2). The highest species richness (28 species) with 92 individuals was found in the Actinopterygii class and the lowest species richness (2 species) with three individuals detected in the Chondrichthyes class. The 150 vertebrate individuals were detected, consist of 92 Actinopterygii fishes, three Chondrichthyes fish, 11 amphibians, seven reptiles, ten aves, and 27 mammals (Table 2).

This study demonstrated the efficiency of the eDNA method to detected all vertebrates class from one $\mathrm{L}$ water sample (duplo) compared to the conventional method (direct organism capture), which must be capture by all organisms. In between 150 individuals identified, 95 individuals $(63 \%)$ were identified up to the species level, and 55 individuals (37\%) unassigned up to the species level (Table 3). Among 95 individuals who identified to species level consists of 54 individuals of class Actinopterygii, three individuals of class Chondrichthyes, 11 individuals of class Amphibia, six individuals of class Reptilia, six individuals of class Aves, and 15 individuals of class Mammalia. While among 55 individuals who unassigned up to the species level consists of 35 individuals only identified to class level, four individuals identified only to order level, 14 individuals identified only to family level, and two individuals identified only to genus level. 
The vertebrate individuals list identified using the eDNA method with the NGS technique shown in Table 3. Among all individuals were detected, only $11 \%$ known living in Maninjau Lake, consists of 16 individuals of fishes species, i.e. Carassius auratus, Cyprinus carpio, Oreochromis niloticus, Gambusia affinis, and Xiphophorus maculatus, while the others $(89 \%)$ are native species to other countries.

\section{Actinopterygii class}

The Actinopterygii has the highest number of individuals (92 individuals) detected compared to the other class. That class consists of 54 individuals identified up to species level, two individuals identified to genus level, 13 individuals only identified to family level, and 23 individuals only identified to class level (unassigned to the clear taxa). In the order level, the highest fish species were detected in Cyprinodontiformes (five species). Among the Actinopterygii were identified (Table 3), 17\% of them known in Maninjau Lake, i.e., Cyprinidae (Carassius auratus and Cyprinus carpio), Cichlidae (Oreochromis niloticus), and Poeciliidae (Gambusia affinis and Xiphophorus maculatus). Two species (Cyprinus carpio and Oreochromis niloticus) are the introduced species from Europe and Africa and become the main aquaculture fish by local people using the floating net cage in Maninjau Lake. Oreochromis niloticus and Cyprinus carpio are species identify using the eDNA method, which also reported in the previous monitoring using the conventional method (direct organism capture). However, the native fish species living in Maninjau Lake such as Rasbora maninjau, Hampala macrolepidota, Tor tambra, Osteochilus hasseltii, and Gobiopterus sp. are not recorded using the eDNA method, while the conventional method (direct organism capture) (Table 1) had detected. While, the other fishes $(83 \%)$ were detected known not living in Maninjau Lake, and also not reported in the previous monitoring using the conventional method (direct organism capture). They are native to Africa, America, Europe, the Atlantic, and the Arctic.

\section{Chondrichthyes class}

Chondrichthyes is the cartilaginous fish class, which monitors three individuals from two species. However, these fishes (Callorhinchus and Rhincodonare) are known as the seawater vertebrate as the native species to America. Therefore, it is impossible to found them in Maninjau Lake.

\section{Amphibia class}

Monitoring using the eDNA method was identified 11 individuals in Amphibia class, where they were assigned to the species level. The highest species detected in this group is Xenopus laevis, which is a native species to Africa and America and introduced to some regions in Africa and Asia, but not found in Indonesia.

\section{Reptilia class}

Our study detected seven individuals from three species of class Reptilia including Crocodylia, Squamata, and Testudines groups. All species are native to America and China and not found in Indonesia.

\section{Aves class}

In the Aves class, ten individuals detected consist of six individuals assigned up to the species level, two individuals only assigned at the order level, and two individuals only gave at the class level (unassigned to the clear taxa). Almost all species detected are native species from Africa and America, and only one species has reported presence in Sumatra (Buceros rhinoceros).

\section{Mammalia class}

Mammalia is the second class with the highest species detected using the eDNA method with the NGS technique. Among the 27 individuals, 15 individuals identified up to the species level, one individual identified up to the family level, one individual only identified up to the order level, and ten individuals between them only identified up to the class level (unassigned to the clear taxa). Rodentia is the order with the highest species from Mammalia, with dominant species from rat groups. All Mammalia members are known as native to Africa, America, Europe, and Australia.

\section{Discussion}

The present study was the first study using the eDNA method for monitoring freshwater vertebrates in Sumatra, especially in Maninjau Lake. The results demonstrated the successful eDNA method to detect the variety of vertebrate classes in Maninjau Lake. The other studies also showed the successful eDNA method for detecting vertebrates i.e., molecular detection of vertebrates (Amphibian and Reptilia) in the Northwestern region of the United States (Goldberg et al. 2011), monitoring endangered freshwater biodiversity in the European natural freshwater systems (Thomsen et al. 2012), census marine fishes in a Large Mesocosm (Open Sea Tank) at the Monterey Bay Aquarium (Kelly et al. 2014), mesocosm fish and amphibian species diversity in the University of Notre Dame (Evans et al. 2016), and diversity study around the Pondok Dadap fish landing station, Malang, Indonesia (Andriyono et al. 2019).

Table 2. Taxa identified using the eDNA method with the NGS technique

\begin{tabular}{lccccc}
\hline \multicolumn{1}{c}{ Class } & Ordo & Family & Genus & Species & $\begin{array}{c}\text { Individual } \\
\text { number }\end{array}$ \\
\hline Actinopterygii & 12 & 17 & 24 & 26 & 92 \\
Chondrichthyes & 2 & 2 & 2 & 2 & 3 \\
Amphibia & 1 & 2 & 2 & 3 & 11 \\
Aves & 6 & 5 & 5 & 5 & 10 \\
Reptilia & 3 & 3 & 3 & 3 & 7 \\
Mammalia & 7 & 9 & 12 & 12 & 27 \\
Total & 31 & 38 & 48 & 51 & 150 \\
\hline
\end{tabular}


Table 3. Individual vertebrates lists identified using the eDNA method with the NGS technique

\begin{tabular}{|c|c|c|c|c|c|}
\hline Class & Ordo & Family & Genus & Specie & $\begin{array}{c}\text { Individual } \\
\text { number }\end{array}$ \\
\hline \multirow[t]{31}{*}{ Actinopterygii } & Beloniformes & Adrianichthyidae & Oryzias & Oryzias latipes & 1 \\
\hline & & & & Oryzias melastigma & 1 \\
\hline & & & Oryzias & & 1 \\
\hline & Characiformes & Characidae & Astyanax & Astyanax mexicanus & 2 \\
\hline & Cichliformes & Cichlidae & Astatotilapia & Astatotilapia calliptera & 1 \\
\hline & & & Oreochromis & Oreochromis niloticus & 2 \\
\hline & & & Pundamilia & Pundamilia nyererei & 1 \\
\hline & & Cichlidae & & & 4 \\
\hline & Cypriniformes & Cyprinidae & Carassius & Carassius auratus & 5 \\
\hline & & & Cyprinus & Cyprinus carpio & 4 \\
\hline & & & Danio & Danio rerio & 5 \\
\hline & & & Sinocyclocheilus & Sinocyclocheilus rhinocerous & 1 \\
\hline & & Cyprinidae & & & 5 \\
\hline & Cyprinodontiformes & Fundulidae & Fundulus & Fundulus heteroclitus & 1 \\
\hline & & Nothobranchiidae & Nothobranchius & Nothobranchius furzeri & 1 \\
\hline & & Poeciliidae & Gambusia & Gambusia affinis & 1 \\
\hline & & & Xiphophorus & Xiphophorus maculatus & 4 \\
\hline & & Rivulidae & Austrofundulus & Austrofundulus limnaeus & 3 \\
\hline & Esociformes & Esocidae & Esox & Esox lucius & 1 \\
\hline & Labriformes & Labridae & Labrus & Labrus bergylta & 3 \\
\hline & Osteoglossiformes & Mormyridae & Paramormyrops & Paramormyrops kingsleyae & 2 \\
\hline & & Osteoglossidae & Scleropages & Scleropages formosus & 1 \\
\hline & Perciformes & Latidae & Lates & Lates calcarifer & 1 \\
\hline & & Nototheniidae & Notothenia & Notothenia coriiceps & 1 \\
\hline & Salmoniformes & Salmonidae & Oncorhynchus & Oncorhynchus mykiss & 4 \\
\hline & & & & Oncorhynchus tshawytscha & 3 \\
\hline & & & Oncorhynchus & & 1 \\
\hline & & & Salmo & Salmo salar & 1 \\
\hline & & Salmonidae & & & 4 \\
\hline & Semionotiformes & Lepisosteidae & Lepisosteus & Lepisosteus oculatus & 3 \\
\hline & Siluriformes & Ictaluridae & Ictalurus & Ictalurus punctatus & 1 \\
\hline Actinopterygii & & & & & 23 \\
\hline \multirow{2}{*}{ Chondrichthyes } & Chimaeriformes & Callorhinchidae & Callorhinchus & Callorhinchus milii & 1 \\
\hline & Orectolobiformes & Rhincodontidae & Rhincodon & Rhincodon typus & 2 \\
\hline \multirow[t]{3}{*}{ Amphibia } & Anura & Pipidae & Xenopus & Xenopus laevis & 6 \\
\hline & & & & Xenopus tropicalis & 4 \\
\hline & & Ranidae & Rana & Rana catesbeiana & 1 \\
\hline \multirow[t]{4}{*}{ Reptilia } & Crocodylia & Alligatoridae & Alligator & Alligator sinensis & 1 \\
\hline & Squamata & Dactyloidae & Anolis & Anolis carolinensis & 4 \\
\hline & Squamata & & & & 1 \\
\hline & Testudines & Emydidae & Chrysemys & Chrysemys picta & 1 \\
\hline \multirow[t]{6}{*}{ Aves } & Bucerotiformes & Bucerotidae & Buceros & Buceros rhinoceros & 1 \\
\hline & Ciconiiformes & Pteroclidae & Pterocles & Pterocles gutturalis & 1 \\
\hline & Coraciiformes & Meropidae & Merops & Merops nubicus & 1 \\
\hline & Musophagiformes & Musophagidae & Tauraco & Tauraco erythrolophus & 1 \\
\hline & Tinamiformes & Tinamidae & Nothoprocta & Nothoprocta perdicaria & 2 \\
\hline & Passeriformes & & & & 2 \\
\hline Aves & & & & & 2 \\
\hline \multirow[t]{13}{*}{ Mammalia } & Cingulata & Dasypodidae & Dasypus & Dasypus novemcinctus & 1 \\
\hline & Eulipotyphla & Soricidae & Sorex & Sorex araneus & 1 \\
\hline & Monotremata & Ornithorhynchidae & Ornithorhynchus & Ornithorhynchus anatinus & 1 \\
\hline & Rodentia & Cricetidae & Mesocricetus & Mesocricetus auratus & 1 \\
\hline & & & Neotoma & Neotoma lepida & 1 \\
\hline & & & Peromyscus & Peromyscus maniculatus & 1 \\
\hline & & Dipodidae & Jaculus & Jaculus jaculus & 1 \\
\hline & & Heteromyidae & Dipodomys & Dipodomys ordii & 2 \\
\hline & & Sciuridae & Ictidomys & Ictidomys tridecemlineatus & 1 \\
\hline & & Sciuridae & & & 1 \\
\hline & Afrosoricida & Chrysochloridae & Chrysochloris & Chrysochloris asiatica & 1 \\
\hline & Artiodactyla & Bovidae & Bos & Bos taurus & 2 \\
\hline & & & Pantholops & Pantholops hodgsonii & 2 \\
\hline \multirow[t]{2}{*}{ Mammalia } & & & & & 10 \\
\hline & Primates & & & & 1 \\
\hline Total & & & & & 150 \\
\hline
\end{tabular}


Our result showed the eDNA method is not yet successfully detected freshwater vertebrates for $100 \%$, especially concerning fish diversity in Maninjau Lake. This study and the other studies using the eDNA method also detected no-target DNA and not detected target DNA, which represented the bias results. Thomsen et al. (2012) reported no-target DNA (bird and deer) detected in the observed pond. Kelly et al. (2014) also failed to identify the Cartilaginous fish and sea turtle in the mesocosms experiment using the eDNA method, which was designed to contain their DNA. From the species detected, 25\% of them were not living in the mesocosms.

The biased results in the present study and the other studies using the eDNA method known as the false positive and the false negative. False-positive detection is the detection of no-target DNA in the sample/system or detection of DNA organisms which not living in the system (Darling and Mahon 2011). All species native from other Asia, Europe, America, Africa, the Atlantic, and the Arctic (89\%) detected by the eDNA method which not living in Maninjau Lake were classified in the false positive. The presence of false-positive from this study may occur due to 1) the possibility of contamination. The possibility of contamination in water samples came from other sources such as wastewater, dead animals, or feces from other predator animals (Rees et al. 2014; Thomsen and Willerslev 2015). This contamination is not detected before because DNA containing in the water samples was identified after reading the sequencing results. 2) Low specificity of the primers and probes and no-target template competition (Darling and Mahon 2011; Rees et al. 2014). In this study, the whole genome DNA sequencing using the universal primer to detected various taxa, thus the possibility of detection of no-target DNA is higher. 3) Nucleotide sequence repositories are unavailable/incomplete (e.g. Genbank) (Shelton et al. 2016). The lack of sequences database was recorded in GenBank as a factor misidentification or unassigned the individuals into the clear taxa.

The other studies also reported the presence of falsepositive detection. Kelly et al. (2014) reported false positives of $8.3 \%$ for the exogenous DNA at the family level and $0.07 \%$ for no-presence groups in the observed mesocosm. Andriyono et al. (2019) also reported that Thunnus thynnus is not inhabitat the Indian and Pacific ocean, but detected by the eDNA method in the Pondok Dadap fish landing station Malang, Indonesia. Andriyono et al. (2019) described that there is two reasons may occur the false positive due to, some samples biased (non-target DNA contaminations, primer biases, and species misidentification) (Sato et al. 2017), and weakness of PCR MiFish primer during the library construction, which is not suitable for tuna fish species.

Besides, a false negative is also found. False-negative is the negative detection of target DNA/organism in the sample, where the organism was present in the system (Darling and Mahon 2011). All fish species living in Maninjau Lake are shown in table 1 which is not detected by the eDNA method, especially for native species, such as
Rasbora maninjau, Hampala macrolepidota, Tor tambra, Osteochilus hasseltii, and Gobiopterus sp. were classified in the false-negative. The false-negative also present in the other study using the eDNA method. Kelly et al. (2014) reported that false-negative detected in census marine water, where is cartilaginous fishes and a sea turtle were found in the tank during sampling was not detected using the eDNA. The mismatches in the $12 \mathrm{~S}$ vertebrate primer cause not detected the cartilaginous fishes and sea turtle thus, the specific primer pair is needed. Laramie et al. (2015) also found $8.2 \%$ of false-negative cases, where is the eDNA method failed to detect the chinook salmon (Oncorhynchus tshawytscha) at a sampling site in Methow and Okanogan Subbasins when the species was present in the system. Laramie et al. (2015) reported the reduction of collection sites as a factor not detected the chinook salmon in subbasin.

The presence of false-negative from this study may occur due to (i) the collection of water samples are not sufficient to represent all the eDNA targets (Andruszkiewicz et al. 2017), (ii) the poor DNA quality (Darling and Mahon 2011; Wilcox et al. 2013), (iii) the bias results during the molecular process (the presence of inhibitor in the PCR process and primer bias) (Dejean et al. 2011; Wilcox et al. 2013), and (iv) nucleotide sequence in Genbank are unavailable/incomplete (Goldberg et al. 2016; Shelton et al. 2016).

Lack of sampling sites in Maninjau Lake is thought to be why not all DNA species are represented. Thus, sampling with an increase in the sampling sites and replications potentially increases the possibility of finding a DNA target and eliminates false negative detection. According to Andruszkiewicz et al. (2017), water sample collection without repetition was no representative of all DNA in the lake waters because of the possibility that the eDNA had not being mixed homogeneously in all water samples. The discrepancy between eDNA is found at different sites and depths, potentially due to the physical factors of eDNA such as density or relationship among the particles. The number of target DNA must be increased by collecting more water samples with many replications at a different location to increase target DNA detection accuracy.

The low amount of DNA can inhibit the PCR process. The amount of target DNA falls below a detection threshold, or DNA molecules with low concentration and low quality could cause the presence of false detection (Darling and Mahon 2011; Wilcox et al. 2013). Besides, the influences of abiotic factors of the DNA degradation such as temperature, $\mathrm{pH}$, UV radiation, salinity, and the presence of bacteria and fungi that contribute to DNA decay should be considered (Strickler et al. 2015).

The PCR will inhibit by several factors, such as (i) humic/fluvic acid, tannins, and the polyphenol in the freshwater systems (Matheson et al. 2010), (ii) complex mixtures of no-target DNA, and (iii) environmental particles which influence the efficiency of primer oligo during the PCR process (Wilcox et al. 2013). The exact selection of the DNA extraction kit can remove the 
inhibitor control during the PCR process. Thus, the specific primers and probe must be designed with high sensitivity to the target DNA and testing the primers prior (Dejean et al. 2011; Wilcox et al. 2013).

The database availability (e.g. GenBank, NCBI) in repositories is very important to detect species and make it easier to assign the species into the correct taxa. The presence of false detection is allegedly associated with the sequence compatibility compared with the available sequences database in Genbank. The unavailable comprehensive database of the target species can cause false detection due to the sequence's incompatibility, as found in this study. Sequences database of fish species in Maninjau Lake, especially native species, such as Rasbora maninjau (Bada) and Gobiopterus sp. (Rinuak) are not yet recorded in GenBank, NCBI. Ratnasingham and Hebert (2007) explained that if the sequences obtained do not match with the available database, the most compatible sequences could be used to determine the possible taxonomic group of the unknown species.

Raw sequence data from sequencing must be carefully filtered to limit false detection to generate reliable taxonomic data. Kelly et al. (2014) reported that the eDNA method inability to detect and classify one fish genus in the clear taxa due to the absence of a $12 \mathrm{~S}$ sequences database in GenBank and found the similarities between Sarda and Thunnus sequences caused the misidentified. Lodge et al. (2012), Taberlet et al. (2012), Thomsen and Willerslev (2015) explained that the identification of samples from eDNA for community surveys is highly dependent on the availability of DNA sequences reference database.

In conclusion, the study results showed that the eDNA method has been successful in detecting the vertebrates in Maninjau Lake. The eDNA method detected 150 vertebrate individuals classify into six classes, 31 orders, 38 families, 48 genera, and 51 species. In between 150 vertebrate individuals were detected consists of 92 Actinopterygii fishes, three Chondrichthyes fishes, 11 amphibians, seven reptiles, ten aves, and 27 mammals. Among all individuals were detected, only $11 \%$ known to live in Maninjau Lake, while the others $(89 \%)$ are native species to other countries. The fishes were detected living in Maninjau Lake by the eDNA method, i.e., Cyprinidae (Carassius auratus and Cyprinus carpio), Cichlidae (Oreochromis niloticus), and Poeciliidae (Gambusia affinis and Xiphophorus maculatus). This study emphasized the importance of basic data on Genbank, in this case, the species which exist in this water.

Therefore, we recommend the monitoring studies using the eDNA method for monitoring biodiversity with considered the increase in the sampling sites and replications and the availability of sequences database in GeneBank, NCBI.

\section{ACKNOWLEDGEMENTS}

The research was supported by the Ministry of Research Technology and Higher Education at Andalas University, Padang, Indonesia (No. T/55/UN.16. 17/PP.ISKRP2GB/LPPM/2019). We thank the Management for the funding support, the Department of Biology, Andalas University for a work permit in the field and laboratory on Genetic and Biomolecular, Faculty of Mathematics and Natural Sciences, Andalas University, Padang, Indonesia and also to students who helped in field and laboratory.

\section{REFERENCES}

Adrianto L, Al Amin MA, Solihin A, Hartoto DI. 2010. Institutional Construction in Fisheries Management in The Decentralization Era. Working Paper PKSPL-IPB. IPB, Bogor. [Indonesian]

Andriyono S, Alam MDJ, Kim H. 2019. Environmental DNA (eDNA) metabarcoding: Diversity study around the Pondok Dadap fish landing station, Malang, Indonesia. Biodiversitas 20 (12): 3772-3781. DOI: 10.13057/biodiv/d201241.

Andruszkiewicz EA, Starks HA, Chavez FP, Sassoubre LM, Block BA, Boehm AB. 2017. Biomonitoring of marine vertebrates in Monterey Bay using eDNA metabarcoding. PLoS One 12 (4): e0176343. DOI: 10.1371/journal.pone.0176343.

Avershina E, Frisli T, Rudi K. 2013. De novo semi-alignment of $16 \mathrm{~s}$ rRNA gene sequences for deep phylogenetic characterization of nextgeneration sequencing data. Microbes Environ 28: 211-216. DOI: 10.1264/jsme2.ME12157.

Cantarel BL, Coutinho PM, Rancurel C, Bernard T, Lombard V, Henrissat B. 2009. The carbohydrate-active enzymes database (cazy): An expert resource for glycogenomics. Nucleic Acids Res 37: D233-D238. DOI: 10.1093/nar/gkn663.

Caporaso JG, Kuczynski J, Stombaugh J, Bittinger K, Bushman FD, Costello EK, Fierer N, Pena AG, Goodrich JK, Gordon JI, Huttley GA, Kelley ST, Knights D, Koenig JE, Ley RE, Lozupone CA, McDonald D, Muegge BD, Pirrung M, Reeder J, Sevinsky JR, Turnbaugh PJ, Walters WA, Widmann J, Yatsunenko T, Zaneveld J, Knight R. 2010. QIIME allows analysis of high-throughput community sequencing data. Nat Methods 7 (5): 335-336. doi:10.1038/nmeth.f.303.

Carim KJ, McKelvey KS, Young MK, Wilcox TM, Schwartz MK. 2016. A Protocol for Collecting Environmental DNA Samples from Streams. Gen Tech Rep RMRS-GTR-355. Department of Agriculture, Forest Service, Rocky Mountain Research Station. Fort Collins, CO, USA.

Darling JA, Mahon AR. 2011. From molecules to management: Adopting DNA based methods for monitoring biological invasions in aquatic environments. Environ Res 111: 978-988. DOI: 10.1016/j.envres.2011.02.001.

Deiner K, Bik HM, Machler E, Seymour M, Lacoursiere-Roussel A, Altermatt F, Creer S, Bista I, Lodge DM, de Vere N, Pfrender ME, Bernatchez L. 2017. Environmental DNA metabarcoding: Transforming how we survey animal and plant communities. Mol Ecol 26: 5872-5895. DOI: 10.1111/ mec.14350.

Dejean T, Valentini A, Miquel C, Taberlet P, Bellemain E, Miaud C. 2012. Improved detection of an alien invasive species through environmental DNA barcoding: The example of the American bullfrog Lithobates catesbeianus. J Appl Ecol 49 (4): 953-959. DOI: 10.1111/j.1365-2664.2012.02171.x.

Eichmiller JJ, Bajer PG, Sorensen PW. 2014. The relationship between the distribution of common carp and their environmental DNA in a small lake. PLoS One 9 (11): e112611. DOI: 10.1371/journal.pone.0112611 PMID: 25383965.

Evans NT, Olds BP, Renshaw MA, Turner CR, Li Y, Jerde CL, Mahon AR, Pfrender ME, Lamberti GA, Lodge DM. 2016. Quantification of Mesocosm fish and amphibian species diversity via environmental DNA metabarcoding. Mol Ecol Resour 16: 29-41. DOI: 10.1111/ 1755-0998.12433.

Ficetola GF, Miaud C, Pompanon F, Taberlet P. 2008. Species detection using environmental DNA from water samples. Biol Lett 4 (4): 423425. DOI: 10.1098/Rsbl. 2008.0118.

Foote A, Thomsen P, Sveegaard S, Wahlberg M, Kielgast J, Kyhn L, Salling A, Galatius A, Orlando L, Thomas M, Gilbert T. 2012. Investigating the potential use of environmental DNA (eDNA) for genetic monitoring of marine mammals. PLoS One 7 (8): e4178. DOI: 10.1371 /journal. pone. 0041781 . 
Goldberg CS, Pilliod DS, Arkle R.S., Waits L.P. 2011. Molecular detection of vertebrates in stream water: A demonstration using Rocky Mountain tailed frogs and Idaho giant Salamanders. PLoS One 6 (7): e22746. DOI: 10.1371/journal.pone.0022746.

Goldberg CS, Turner CR, Deiner K, Klymus KE, Thomsen PF, Murphy MA, Spear SF, McKee A, Oyler-McCance SJ, Cornman RS, Laramie MB, Mahon AR, Lance RF, Pilliod DS, Strickler KM, Waits LP, Fremier AK,Takahara T, Herder JE, Taberlet P. 2016. Critical considerations for the application of environmental DNA methods to detect aquatic species. Methods Ecol Evol 7 (11): 1299-1307. DOI 10.1111/ 2041-210X.12595.

Goldberg C. 2017. Environmental DNA Protocol for Freshwater Aquatic Ecosystems version 2.2. Washington State University, Washington.

Huson DH, Mitra S, Ruscheweyh H, Weber N, Schuster SC. 2011. Integrative analysis of environmental sequences using MEGAN 4. Genome Res 21: 1552-1560. DOI: 10.1101/gr. 120618.11.

Kanehisa M, Goto S, Hattori M, Aoki-Kinoshita KF, Itoh M, Kawashima S, Katayama T, Araki M, Hirakawa M. 2006. From genomics to chemical genomics: new developments in KEGG. Nucleic Acids Res 34: D354-D357. DOI: 10.1093/ nar/gkj102.

Kanehisa M, Goto S, Sato Y, Kawashima M, Furumichi M, Tanabe M. 2014. Data, information, knowledge and principle: back to metabolism in KEGG. Nucleic Acids Res 42: D199-D205. DOI: 10.1093/nar/gkt1076.

Karlsson FH, Tremaroli V, Nookaew I, Bergstrom G, Behre CJ, Fagerberg B, Nielsen J, Backhed F. 2013. Gut metagenome in European women with normal, impaired and diabetic glucose control. Nature 498: 99103. DOI: $10.1038 /$ nature 12198 .

Kelly RP, Port JA, Yamahara KM, Crowder LB. 2014. Using environmental DNA to census marine fishes in a large mesocosm. PLoS One 9 (1): e86175. DOI: 10.1371/journal. pone.0086175.

Laramie MB, Pilliod DS, Goldberg CS. 2015. Characterising the distribution of an endangered salmonid using eDNA analysis. Biol Conserv 183: 29-37. DOI: 10.1016/j.biocon.2014.11.025.

Lodge DM, Turner CR, Jerde CL, Barnes MA, Chadderton WL, Egan SP, Feder JL, Mahon AR, Pfrender ME. 2012. Conservation in a cup of water: Estimating biodiversity and population abundance from environmental DNA. Mol Ecol 21 (11): 2555-2558. DOI: 10.1111/j.1365-294x.2012.05600.x.

Luo R, Liu B, Xie Y, Li Z, Huang W, Yuan J, He G, Chen Y, Pan Q, Liu Y, Tang J, Wu G, Zhang H, Shi Y, Liu Y, Yu C, Wang B, Lu Y, Han C, Cheung DW, Yiu S, Peng S, Xiaoqian Z, Liu G, Liao X, Li Y, Yang H, Wang J, Lam T, Wang J. 2012. SOAP denovo2: An empirically improved memory-efficient short-read denovo assembler. Giga Sci 1 (1) :1-18. DOI: 10.1186/ 2047-217X-1-18.

Mardis ER. 2008. The impact of next-generation sequencing technology on genetics. Trends Genet 24 (3): 133-141. DOI: 10.1016/j.tig.2007.12.007

Matheson C, Gurney C, Esau N, Lehto R. 2010. Assessing PCR inhibition from humic substances. The Open Enzyme Inhibition J 3: 38-45.

Mende DR, Waller AS, Sunagawa S, Jarvelin AI, Chan MM, Arumugam M, Raes J, Bork P. 2012. Assessment of metagenomic assembly using simulated Next Generation Sequencing data. PLoS One 7 (2): e31386. DOI: 10.1371 /journal. pone. 0031386

Metzker ML. 2010. Sequencing technologies -the next generation. Nat Rev Genet 11 (1): 31-46. DOI: 10.1038/nrg2626.

Nathan LR, Jerde CL, Budny ML, Mahon AR. 2014. The use of environmental DNA in invasive species surveillance of the Great Lakes commercial bait trade. Conserv Biol 29 (2): 430-439. DOI: 10.1111/cobi.12381

Ogram A, Sayler GS, Barkay T. 1987. The extraction and purification of microbial DNA from sediments. J Microbiol Methods 7: 57-66. DOI: 10.1016/0167-7012(87)90025-X

Powell S, Forslund K, Szklarczyk D, Trachana K, Roth A, Huerta-Cepas J, Gabaldon T, Rattei T, Creevey C, Kuhn M, Jensen LJ, von Mering C, Bork P. 2013. eggNOG v4. 0: Nested orthology inference across 3686 organisms. Nucleic Acids Res 42: D231-D239. DOI: 10.1093/nar/gkt1253

Putri IAP, Thoha M, Nadjib M, Endah NH, Dalimunthe SA. 2020. The Dilemma of Managing Multifunctional Perspectives and Economics. LIPI Press, Jakarta. [Indonesian]

Qin N, Yang F, Li A, Prifti E, Chen Y, ShaO L, Guo J, le Chatelier E, Yao J, Wu L, Zhou J, Ni S, Liu L, Pons N, Batto JM, Kennedy SP, Leonard P, Yuan C, Ding W, Chen Y, Hu X, Zheng B, Qian G, Xu W, Ehrlich SD, Zheng S, Li L. 2014. Alterations of the human gut microbiome in liver cirrhosis. Nature 513: 59-64. DOI: 0.08/nature68.
Ratnasingham S, Hebert PDN. 2007. BOLD: The barcode of life data system. (www.barcodinglife.org). Mol Ecol Notes 7: 355-364. DOI: 10.1111/j. 1471-8286.2006.01678.x.

Rees HC, Maddison BC, Middleditch DJ, Patmore JRM, Gough KC. 2014. Review: The detection of aquatic animal species using environmental DNA- A Review of eDNA as a survey tool in ecology. J Appl Ecol 51: 1450-1459. DOI: 10.1111/1365-2664.12306.

Roesma DI. 2011. Species Diversity and Genetic Relationship of Cyprinidae in Lakes and the Adjoining Rivers in West Sumatra. Dissertation. Andalas University, Padang. [Indonesian]

Roesma DI, Chornelia A, Mursyd A, Kamsi M. 2016. Fish diversity of the Batang Toru River System, South Tapanuli, North Sumatra. Biodiversitas 17 (2): 628-634. DOI: 10.13057/biodiv/d170235.

Roesma DI, Djong HT, Munir W, Agesi AV, Chornelia A. 2017. Genetic diversity of Tor douronensis (Pisces: Cyprinidae) in West Sumatra, Indonesia. Biodiversitas 18 (3): 1018-1025. DOI: 10.13057/biodiv/d180320.

Roesma DI, Djong HT, Munir W, Aidil DR. 2018. New record species of Puntius (Pisces: Cyprinidae) from West Sumatra Based on Cytochrome Oxidase I Gene. Int J Adv Sci Eng Inf Technol 8 (1): 250-256. DOI: 10.18517/ijaseit.8.1.4170.

Roesma DI, Tjong DH, Karlina W, Aidil DR. 2019. Taxonomy confirmation of puntius cf. binotatus from Gunung Tujuh lake, Jambi, Indonesia based on cytochrome oxidase I (COI) gene. Biodiversitas 20 (1): 54-60. DOI: 10.13057/biodiv/d200107.

Roesma DI, Tjong DH, Aidil DR. 2020. Phylogenetic analysis of transparent gobies in three Sumatran lakes, inferred from mitochondrial Cytochrome Oxidase I (COI) gene. Biodiversitas 21 (1): 43-48. DOI: $10.13057 /$ biodiv/d210107.

Sato H, Sogo Y, Doi H, Yamanaka H. 2017. Usefulness and limitations of sample pooling for environmental DNA metabarcoding of freshwater fish communities. Sci Rep 7: 14860. DOI: 10.1038/s41598-01714978-6.

Shelton AO, O'Donnell JL, Samhouri JF, Lowell N, Williams GD, Kelly RP. 2016. A framework for inferring biological communities from environmental DNA. Ecol Appl 26 (6): 1-47. DOI: 10.1890/151733.1

Shendure J, Ji H. 2008. Review: Next-generation DNA sequencing. Nat Biotechnol 26 (10) :1135-1145. DOI: 10.1038/nbt1486.

Shokralla S, Porter TM, Gibson JF, Dobosz R, Janzen DH, Hallwachs WG, Golding B, Hajibabaei M. 2015. Massively parallel multiplex DNA sequencing for specimen identification using an Illumina MiSeq platform. Sci Rep 5 (1): 9687. DOI: 10.1038/srep09687.

Shokralla S, Spall JL, Gibson JF, Hajibabaei M. 2012. Next-generation sequencing technologies for environmental DNA research. Mol Ecol 21: 1794-1805. DOI: 10.1111/J.1365-294x.2012.05538.X.

Strickler KM, Fremier AK, Goldberg CS. 2015. Quantifying effects of UV-B, temperature, and $\mathrm{pH}$ on eDNA degradation in aquatic microcosms. Biol Conserv 183: 85-92. DOI: 10.1016/j.biocon.2014.11.038.

Taberlet P, Coissac E, Hajibabaei M, Rieseberg, LH. 2012. Environmental DNA. Mol Ecol 21: 1789-1793. DOI: 10.1111/j.1365-294X. 2012. 05542.x.

Takahara T, Minamoto T, Doi H. 2015. Effects of sample processing on the detection rate of environmental DNA from the common carp (Cyprinus carpio). Biol Conserv 183: 64-69. DOI: 10.1016/j.biocon.2014.11.014.

Thomsen PF, Kielgast J, Iversen LL, Wiuf C, Rasmussen M, Gilbert TP, Orlando L, Willerslev E. 2012. Monitoring endangered freshwater biodiversity using environmental DNA. Mol Ecol 21: 2565-2573. DOI: 10.1111/J.1365-294X.2011.05418.X.

Thomsen PF, Willerslev E. 2015. Environmental DNA an emerging tool in conservation for monitoring past and present biodiversity. Biol Conserv 183: 4-18. DOI: 10.1016/j.biocon.2014.11.019.

Treguier A, Paillisson JM, Dejean T, Valentini A, Schlaepfer MA, Roussel JM. 2014. Environmental DNA surveillance for invertebrate species: Advantages and technical limitations to detect invasive crayfish Procambarus clarkii in freshwater ponds. J Appl Ecol 51: 871-879. DOI: 10.1111/ 1365-2664.12262.

White JR, Nagarajan N, Pop M. 2009. Statistical methods for detecting differentially abundant features in clinical metagenomic samples. $\begin{array}{lllll}\text { PLoS Comput Biol } 5 & \text { (4): e1000352. DOI: }\end{array}$ 10.1371/journal.pcbi.1000352.

Wilcox TM, McKelvey KS, Young MK, Jane SF, Lowe WH, Whiteley A, Schwartz MK. 2013. Robust detection of rare species using 
environmental DNA: The importance of primer specificity. PLoS ONE 8 (3): e59520. doi:10.1371/journal.pone.0059520.

Willerslev E, Hansen AJ, Binladen J, Brand TB, Gilbert MTP, Shapiro B, Bunce M, Wiuf C, Gilichinsky DA, Cooper A. 2003. Diverse plant and animal genetic records from Holocene and Pleistocene sediments. Sci 300: 791-795. DOI: 10.1126/science.1084114.

Yoccoz NG, Brathen KA, Gielly L, Haile J, Edwards ME, Goslar T, von Stedingk H, Brysting AK, Coissac E, Pompanon F, Sonstebo JH,
Miquel C, Valentini A, de Bello F, Chave J, Thuiller W, Wincker P, Cruaud C, Gavory F, Rasmussen M, Gilbert MTP, Orlando L, Brochmann C, Willerslev E, Taberlet P. 2012. DNA from soil mirrors plant taxonomic and growth form diversity. Mol Ecol 21: 3647-3655. DOI: 10.1111/J.1365-294X. 2012.05545.X.

Zhu W, Alexandre L, Mark B. 2010. Ab initio gene identification in metagenomic sequences. Nucleic Acids Res 38 (12): e132-e132. DOI: 10. $1093 / \mathrm{nar} / \mathrm{gkq} 275$. 